\title{
Real-time uptake of fluorescent ASP+ via the organic cation transporter 3
}

\author{
Felix P Mayer ${ }^{1}$, Diethart Schmid ${ }^{1}$, Marion Holy¹, Jae-Won Yang ${ }^{1}$, Isabella Salzer ${ }^{1}$, Stefan Boehm¹, Peter Chiba², \\ Harald H Sitte \\ From 18th Scientific Symposium of the Austrian Pharmacological Society (APHAR). Joint meeting with the \\ Croatian, Serbian and Slovenian Pharmacological Societies. \\ Graz, Austria. 20-21 September 2012
}

\section{Background}

The organic cation transporter 3 (OCT3) shows a broad expression pattern in the nervous system and has been detected in glial cells and neurons. Here, OCT3 serves as an additional high-capacity, low-affinity reuptake system for monoamine neurotransmitters such as norepinephrine, serotonin and dopamine, and therefore OCT-mediated uptake has been termed "uptake 2".

\section{Methods}

We used the mouse and human isoforms of OCT3 and stably expressed them in HEK 293 cells. We measured OCT3-mediated uptake of the fluorescent substrate 4-Di-1-ASP (4-(4-(dimethylamino)styryl)- $N$-methylpyridinium (ASP+) in real-time. Uptake of tritiated 1-methyl-4phenylpyridinium was measured in comparison to the fluorescent uptake measurements. We used mass spectrometry to assess the phosphorylation status of OCT3.

\section{Results}

We show that ASP+ is selectively taken up via OCT3 in real time. ASP+ uptake allows for sensitive assessment of transport via OCT3 and hence, we exploited the mode of action of several OCT3 substrates and transport inhibitors such as the stress hormone corticosterone. All results with the fluorescent ASP+ are in line with previously published reports. Finally, we tested if OCT-mediated uptake is sensitive to phosphorylation and observed that GF109203X inhibited uptake.

\footnotetext{
* Correspondence: harald.sitte@meduniwien.ac.at

${ }^{1}$ Center for Physiology and Pharmacology, Medical University of Vienna, 1090 Vienna, Austria
}

Full list of author information is available at the end of the article

\section{Conclusions}

Uptake by OCT3 can be measured with the fluorescent ligand ASP+; this uptake is comparable to the uptake of radioactively labeled $\mathrm{MPP}+$. Uptake inhibition by corticosterone was comparable using either $\mathrm{ASP}+$ or $\mathrm{MPP}+$ and similar to inhibition of protein kinase $C$.

\section{Acknowledgements}

Supported by the Austrian Science Fund (FWF, grant F3506).

\section{Author details}

${ }^{1}$ Center for Physiology and Pharmacology, Medical University of Vienna, 1090 Vienna, Austria. ${ }^{2}$ Institute of Medical Chemistry, Medical University of Vienna, 1090 Vienna, Austria.

Published: 17 September 2012

doi:10.1186/2050-6511-13-S1-A80

Cite this article as: Mayer et al:: Real-time uptake of fluorescent ASP+ via the organic cation transporter 3. BMC Pharmacology and Toxicology 2012 13(Suppl 1):A80.

Submit your next manuscript to BioMed Central and take full advantage of:

- Convenient online submission

- Thorough peer review

- No space constraints or color figure charges

- Immediate publication on acceptance

- Inclusion in PubMed, CAS, Scopus and Google Scholar

- Research which is freely available for redistribution

Submit your manuscript at www.biomedcentral.com/submit
() Biomed Central

\section{Ciomed Central}

